\title{
PENGARUH PEMBERIAN KETAMIN TERHADAP DERAJAT INFLAMASI MUKOSA USUS PADA TIKUS MODEL SEPSIS
}

\author{
Sindu Sintara ${ }^{1}$, Aswoco Andyk Asmoro, Wiwi Jaya ${ }^{1}$ \\ ${ }^{1}$ Fakultas Kedokteran Universitas Brawijaya Malang
}

Email : shinshintara@gmail.com

\begin{abstract}
ABSTRAK
Latar Belakang.Sepsis dapat mengakibatkan hilangnya pertahanan mukosa usus sehingga menyebabkan translokasi produk bakteri ke dalam sirkulasi darah yang meningkatkan inflamasi pada organ lain. Pemberian ketamin secara intraperitoneal diharapkan dapat menurunkan derajat inflamasi pada mukosa usus yang akan mengurangi terjadinya sepsis sehingga menurunkan morbiditas maupun mortalitas akibat sepsis. Tujuan.Mengetahui perbedaan derajat inflamasi dan pengaruh perbedaan waktu pemberian ketamin terhadap derajat inflamasi usus tikus. Metode.Penelitian menggunakan metode experimental, dengan sampel hewan coba tikus putih rattus norvegicus dari galur wistar model sepsis menggunakan metode fecal induced peritonitis (FIP). Sampel dibagi menjadi enam kelompok perlakuan yaitu : kontrol negatif (-), kontrol positif (+), pemberian ketamin $5 \mathrm{mg} / \mathrm{kgbb}$ pada jam ke-0 (A), ke-3 (B), ke-5 (C) dan pemberian berturut-turut pada jam ke 0,2,4 (D). Analisa data menggunakan kruskal wallis dan regresi sederhana. Hasil.Analisis kruskal wallis diperoleh nilai signifikansi sebesar $0,000(\mathrm{p}<0,05)$ yang menunjukkan ada perbedaan bermakna antar tiap kelompok perlakuan. Hasil uji regresi didapat nilai koefisien korelasi sebesar 0,730 dan nilai $\mathrm{R}^{2}$ yaitu 0,533 yang menunjukkan waktu pemberian ketamin berpengaruh positif terhadap derajat inflamasi mukosa usus tikus model sepsis. Kesimpulan. Waktu pemberian ketamin berpengaruh positif terhadap derajat inflamasi mukosa usus tikus serta terdapat perbedaan derajat inflamasi pada setiap kelompok perlakuan pemberian ketamin.
\end{abstract}

Kata Kunci : Ketamin, derajat inflamasi

\begin{abstract}
Background.Sepsis can eliminate the defense of intestinal mucosa. Intraperitoneal administration of ketamine is expected to reduce the degree of inflammation in the intestinal mucosa which will reduce the occurrence of sepsis. Objective.This study was to evaluatedifference in the degree of inflammation and the influence of ketamine administration time. Methods. This study used an experimental method, with animal samples of rattus norvegicus white rats from the septic model wistar strain using fecal induced peritonitis (FIP) method. Samples divided into six groups: negative control (-), positive control (+), administration of ketamine $5 \mathrm{mg} / \mathrm{kg}$ at hour 0 (A), 3rd (B), 5th (C) and every two hour to 0.2.4 (D). Data analysis uses kruskal wallis and simple regression. Results. Kruskal wallis analysis obtained a significance value of $0.000(p<0.05)$ which showed there were significant differences between each group. Regression test results obtained correlation coefficient value of 0.730 and R2 value of 0.533 , it showed the time of administration ketamine has a positive effect on the degree of inflammation of the sepsis mice intestinal mucosa. Conclusion. The time of administration ketamine had a positive effect on the degree of inflammationon rat intestinal mucosa and there were differencesfrom the degree of inflammation in each group given ketamine.
\end{abstract}

Keywords : Ketamine, degree of inflammation 


\section{PENDAHULUAN}

Sepsis dan Systemic Inflamatory Respon Syndrome (SIRS) berkaitan dengan kerusakan dan gagalnya fungsi saluran pencernaan.Gagalnya fungsi saluran pencernaan adalah masalah yang sering terjadi selama sepsis yang mengakibatkan hilangnya pertahanan mukosa usus, peningkatan permeabilitas mukosa dan translokasi dari produk-produk bakteri ke dalam sirkulasi darah yang berlanjut meningkatnya respon inflamasi pada organ-organ yang lain, sehingga mengakibatkan MOD serta kematian.Mekanisme yang mendukung perusakan saluran cerna adalah apoptosis yang meningkat. Peningkatan apoptosis saluran pencernaan yang berlebihan akan mendukung ternyadinya atrofi, perusakan dan gangguan fungsi pertahanan mukosa saluran pencernaan (Alscher et al., 2001).

Sepsis disebabkan oleh mikroorganisme seperti bakteri gram negatif maupun positif, jamur, virus dan parasit (O’Brien et al., 2005).Komponen utama dari bakteri gram negatif yang berperan penting terhadap sepsis adalah lipopolisakarida (LPS).LPS langsung mengaktifkan sistem imun seluler maupun humoral yang dapat menimbulkan perkembangan septicemia. LPS memicu sitokin proinflamasi melalui aktivasi gen nuclear faktor kB (NF-kB) (Guntur, 2006). NFkB diaktivasi oleh stimulus dari sitokin inflamasi seperti tumornecrosisfactor (TNF-á), interlenkin(IL-1, sinyal aktivasi sel T, dan induksi stress (Tripathi dan Aggarwal, 2006).

Ketamin adalah obat anestesi yang mempunyai efek stimulasi terhadap kardiovaskuler, meningkatkan cardiacoutput dan systemicvaskuler resistance melalui stimulasi pada system saraf simpatis, menghasilkan pelepasan dari katekolamin (Loix, 2011). Ketamin menurunkan inflamasi pada liver yang diinduksi lipopolisakarida melalui penurunan cyclooxygenase-2, protein nitrat oksida sintase, dan NF-kB. Hal ini menunjukkan bahwa ketamin dapat memiliki sifat anti-inflamasi yang dibuktikan secara in vivo (Hirota dan Lambert, 2011).Pemberian ketamin juga dilaporkan dapat meningkatkan survival rate tikus yang mendapat perlakuan sepsis. Efek ini diduga karena penghambatan sitokin proinflamasi IL-6 (Gurfinkel, 2006).

Kemampuan ketamin menurunkan cyclooxygenase-2, protein nitrat oksida sintase, dan NF-kB sebagai anti inflamasi diharapkan mampu menggurangi SIRS. Tempat terjadinya SIRS yang paling sering adalah saluran pencernaan yaitu usus atau abdomen (Munford, 2006). Pemberian ketamin secara intra peritoneal diharapkan dapat menurunkan derajat inflamasi pada mukosa usus yang selanjutnya akan menngurangi terjadinya sepsis sehingga dapat menurunkan morbiditas maupun mortalitas akibat sepsis.

\section{METODE PENELITIAN}

Penelitian ini merupakan penelitian experimental dengan desain true experimental laboratory dengan metode Randomized Posttest Only Controlled Group Design. Sampel menggunakan hewan coba tikus putih Rattus Norvegicus dari galur wistar dengan kriteria inklusi tikus jantan, sehat umur 5 bulan, berat badan 200-250 gram, dan belum mengalami perlakuan apapun. Jumlah sampel sebanyak 30 ekor tikus yang dibagi menjadi enam (6) kelompok perlakuan yaitu $\mathrm{KN}(-)$ kelompok kontrol negatif tikus yang tidak mendapat perlakuan apapun, $\mathrm{KN}(+)$ kelompok kontrol positif tikus yang diinduksi sepsis dengan metode Fecal Induced Peritonitis (FIP) namun tidak diberikan ketamin, $\mathrm{KP}(\mathrm{A})$ : Tikus yang diinduksi sepsis dan diberikan ketamin $5 \mathrm{mg} / \mathrm{kgbb}$ intraperitoneal pada jam ke $0, \mathrm{KP}(\mathrm{B})$ : Tikus yang diinduksi sepsis dan diberikan ketamin $5 \mathrm{mg} / \mathrm{kgbb}$ intraperitoneal pada jam ke 3, $\mathrm{KP}(\mathrm{C})$ : Tikus yang diinduksi sepsis dan diberikan ketamin $5 \mathrm{mg} / \mathrm{kgbb}$ intraperitoneal pada jam ke 5, KP(D) : Tikus yang diinduksi sepsis dan diberikan ketamin dosis $5 \mathrm{mg} /$ kgbb intraperitoneal tiap 2 jam (jam ke 0,2,4). Pada jam ke-6 setelah pemberian FIP dilakukan pembedahan tikus untuk diamati derajat inflamasinya berdasarkan sel-sel radang.

Uji komparasi kelompok, dilakukan dengan uji one-way anova, apabila setelah dilakukan uji prasyarat parametrik didapatkan hasil sebaran data normal. Apabila pada uji prasyarat parametrik, didapatkan hasil sebaran data tidak normal akan dilakukan uji non parametrik yaitu uji Kruskal Wallis.

\section{HASIL PENELITIAN}

Hasil pengamatan mikroskopis terhadap derajat inflamasi usus pada tiap kelompok dapat dilihat pada tabel berikut : 
Tabel 1. Pembagian Kelompok Perlakuan

\begin{tabular}{lclllll}
\hline No & \multicolumn{7}{c}{ Kelompok } & C & D \\
\cline { 2 - 7 } & $\mathbf{N}$ & $\mathbf{P}$ & $\mathbf{A}$ & $\mathbf{B}$ & $\mathbf{C}$ & 1 \\
$\mathbf{1}$ & 1 & 4 & 2 & 3 & 4 & 1 \\
$\mathbf{2}$ & 1 & 3 & 2 & 2 & 3 & 1 \\
$\mathbf{3}$ & 2 & 4 & 2 & 2 & 3 & 1 \\
$\mathbf{4}$ & 1 & 3 & 2 & 3 & 3 & 2 \\
$\mathbf{5}$ & 2 & 4 & 1 & 4 & 3 & \\
\hline
\end{tabular}

Hasil pengukuran derajat inflamasi dari masing-masing perlakuan disajikan pada tabel berikut :

Tabel 2. Statistik Deskriptif Derajat Inflamasi Mukosa Usus Tikus

\begin{tabular}{cccccc}
\hline Perlakuan & N & Mean & Std. Dev. & Min & Max \\
\hline K- & 5 & 1,40 & 0,548 & 1 & 2 \\
K+ & 5 & 3,60 & 0,548 & 3 & 4 \\
A & 5 & 1,80 & 0,447 & 1 & 2 \\
B & 5 & 2,80 & 0,837 & 2 & 4 \\
C & 5 & 3,20 & 0,447 & 3 & 4 \\
D & 5 & 1,20 & 0,447 & 1 & 2 \\
\hline
\end{tabular}

Berdasarkan rata-rata dapat dikatakan bahwa perlakuan D (Tikus yang dilakukan induksi sepsis dengan metode FIP jam ke 0 dan dilakukan pemberian ketamin dengan dosis $5 \mathrm{mg} / \mathrm{kgbb}$ intraperitoneal tiap 2 jam (jam ke 0,2,4)) merupakan perlakuan yang paling baik dalam menurunkan derajat inflamasi mukosa usus tikus yang telah terinduksi sepsis.
Hasil analisis Kruskal Wallis didapat nilai signifikasi 0,000 yang berarti terdapat perbedaan yang signifikan derajat inflamasi mukosa usus tikus pada berbagai perlakuan. Uji Mann-Whitney merupakan analisis lanjutan dalam uji kruskal-wallis Halis uji Mann-Whitney ditampilkan pada tabel berikut :

Tabel 3.Hasil Uji Mann-Whitney

\begin{tabular}{cccc}
\hline No & Perbandingan perlakuan & Nilai Sig. & Ke terangan \\
\hline $\mathbf{1}$ & $\mathrm{K}(-)-\mathrm{K}(+)$ & 0,007 & Berbeda signifikan \\
$\mathbf{2}$ & $\mathrm{K}(-)-\mathrm{A}$ & 0,221 & Tidak Berbeda signifikan \\
$\mathbf{3}$ & $\mathrm{K}(-)-\mathrm{B}$ & 0,021 & Berbeda signifikan \\
$\mathbf{4}$ & $\mathrm{K}(-)-\mathrm{C}$ & 0,006 & Berbeda signifikan \\
$\mathbf{5}$ & $\mathrm{K}(-)-\mathrm{D}$ & 0,513 & Tidak Berbeda signifikan \\
$\mathbf{6}$ & $\mathrm{K}(+)-\mathrm{A}$ & 0,006 & Berbeda signifikan \\
$\mathbf{7}$ & $\mathrm{K}(+)-\mathrm{B}$ & 0,118 & Tidak Berbeda signifikan \\
$\mathbf{8}$ & $\mathrm{K}(+)-\mathrm{C}$ & 0,221 & Tidak Berbeda signifikan \\
$\mathbf{9}$ & $\mathrm{K}(+)-\mathrm{D}$ & 0,006 & Berbeda signifikan \\
$\mathbf{1 0}$ & $\mathrm{A}-\mathrm{B}$ & 0,045 & Berbeda signifikan \\
$\mathbf{1 1}$ & $\mathrm{A}-\mathrm{C}$ & 0,005 & Berbeda signifikan \\
$\mathbf{1 2}$ & $\mathrm{A}-\mathrm{D}$ & 0,072 & Tidak Berbeda signifikan \\
$\mathbf{1 3}$ & $\mathrm{B}-\mathrm{C}$ & 0,343 & Tidak Berbeda signifikan \\
$\mathbf{1 4}$ & $\mathrm{B}-\mathrm{D}$ & 0,012 & Berbeda signifikan \\
$\mathbf{1 5}$ & $\mathrm{C}-\mathrm{D}$ & 0,005 & Berbeda signifikan \\
\hline
\end{tabular}


Perlakuan pemberian ketamine yang baik dilihat dari derajat inflamasi mukosa tikus terendah adalah perlakuan A dan perlakuan D karena hasil pengujian menunjukkan bahwa kedua perlakuan ini memiliki derajat inflamasi yang tidak berbeda signifikan dengan perlakuan kontrol (-), sedangkan perlakuan yang tidak dianjurkan adalah perlakuan $\mathrm{B}$ dan $\mathrm{C}$ karena dari hasil analisis kedua perlakuan ini memiliki derajat inflamasi yang tidak berbeda signifikan dengan kontrol (+) di mana derajat inflamasinya masih tinggi.

Hasil uji regresi diperoleh sig $=0,002$ yang berarti bahwa waktu pemberian ketamin berpengaruh signifikan terhadap derajat inflamasi mukosa usus tikus (nilai sig. $<0,05$ ). Koefisien korelasi sebesar 0,730 menunjukkan besarnya hubungan antara waktu pemberian ketamin dengan derajat inflamasi. Besarnya pengaruh waktu pemberian ketamine terhadap peningkatan derajat inflamasi sebesar 53,3\% (R2=0,533). Tanda koefisien waktu pemberian ketamine $(\mathrm{X})$ adalah positif, artinya semakin lama waktu pemberian ketamine setelah adanya induksi sepsis maka akan mengakibatkan tingginya derajat inflamasi mukosa usus tikus atau sebaliknya semakin cepat pemberian ketamine maka akan menurunkan derajat inflamasi mukosa usus tikus.

\section{PEMBAHASAN}

Paparan LPS yang akan menyebabkan terjadinya sepsis digambarkan dengan adanya pelepasan sitokin proinflamasi seperti TNF-á, IL1â,IL-8 yang berhubungan dengan kerusakan endotel dan jaringan. Efek paparan LPS menyebabkan pelepasan beberapa sitokin (TNF, NFkB,IL-1,IL-8,NO) sebagai pertahanan terhadap benda asing yang memiliki dampak positif dan negatif terhadap tubuh. Dampak yang timbul akibat pelepasan sitokin menyebabkan efek inflamasi.

Faktor transkripsi NF-kB mempunyai peranan krusial pada proses inflamasi. Aktivasi $\mathrm{NF}-\mathrm{Kb}$ dapat menuju kearah transkripsi dari protein-protein proinflamasi. Ketamin menghambat aktivasi NF-kB melalui penekanan degradasi IkB-á dan translokasi NF-kB sehingga akan menghambat produksi sitokain proinflamasi. Ketamin mensupresi produksi LPS-induced TNF,IL-6 dan IL-8 dan rhTNF - induced IL-6andIL-8 dalam darah manusia. TNF -adalah sitokin pertama yang timbul setelah stimulasi LPS, yang kemudian menstimulasi sekresi IL-6andIL-8 dari makrofag monosit, neutrofil, dan sel endotel. Supresi ketamin pada produksi LPS inducedIL-6 and IL-8 disebabkan efek inhibisi ketamin pada produksi LPS-induced TNF- .

Pada penelitian ini, kelompok kontrol negative $(\mathrm{N})$ menunjukkan gambaran histologis usus tikus yang normal grade1. Beberapa diantaranya menunjukkan gambaran histologis usus dengan grade2. Hal ini kemungkinan karena adanya variable luar yang tidak dapat dikendalikan seperti kepekaan mencit terhadap suatu zat,kondisi psikologis mencit, maupun kondisi awal usus mencit.

Pemberian material Fecal Induced Peritonitis (FIP) pada kelompok kontrol positif (P) menyebabkan meningkatnya derajat inflamasi usus tikus secara bermakna yaitu sebagian besar menunjukkan grade 4 seperti yang disajikan pada tabel 1 Pemberian material secara FIP menggambarkan keadaan klinis peritonitis yang disebabkan infeksi polimikroba, adanya infeksi kuman patogen tersebut pada subjek penelitian merupakan penyebab terjadinya sepsis (Kirsten, $\mathrm{P}$ et al. 2003). Menurut Alscher etal.,2001 bahwa proses patologik yang utama pada sepsis adalah apoptosis dari saluran pencernaan, termasuk intestinal. Proses ini menyebabkan hipoperfusi intestinal berupa gangguan mikro sirkulasi mukosa intestinal, disfungsi barrier intestinal dengan peningkatan permeabilitas usus, invasi bakteri pathogen dan translokasi toksinnya kedalam sirkulasi darah serta pelepasan sitokin inflamasi yang berlebihan seperi TNF-á,IFN-ã,IL-1â dan IL-6 yang merupakan tanda reaksi inflamasi (Birnbaum etal.,2006).

Pemberian ketamine langsung setelah keadaan sepsis pada jam ke - O (kelompokA) dapat menurunkan derajat inflamasi usus secara bermakna (Tabel1). Kelompok ini memperlihatkan sebagian besar tikus menunjukkan derajat inflamasi usus pada grade $2 \mathrm{dan}$ ada satu tikus yang menunjukkan grade 1. Namun pada kelompok tikus yang diberikan ketamine 3 jam (kelompok B) dan 5 jam (kelompok C) sesudah di induksi FIP menunjukkan sebagian besar tikus telah mengalami derajat inflamasi pada grade 3 bahkan ada yang mencapai grade 4 pada kedua kelompok tersebut. Hasil pengujian statistic menggunakan Uji Mann Whitney bahwa perlakuan yang tidak berbeda signifikan yaitu $\mathrm{K}(-)$ dengan perlakuan A, K (-) dengan perlakuan $\mathrm{D}, \mathrm{K}(+)$ dengan perlakuan $\mathrm{B}, \mathrm{K}$ $(+)$ dengan perlakuan $\mathrm{C}$, perlakuan $\mathrm{A}$ dengan 
Perlakuan D serta perbandingan perlakuan B dengan perlakuan C. Artinya perlakuan pemberian ketamine yang baik yang akan menghasilkan derajat inflamasi mukosa tikus terendah adalah perlakuan A dan perlakuan $\mathrm{D}$ karena hasil pengujian menunjukkan bahwa kedua perlakuan ini memiliki derajat inflamasi yang tidak berbeda signifikan dengan perlakuan kontrol (-). Sedangkan perlakuan yang tidak dianjurkan adalah perlakuan $\mathrm{B}$ dan $\mathrm{C}$ karena dari hasil analisis kedua perlakuan ini memiliki derajat inflamasi yang tidak berbeda signifikan dengan kontrol (+) di mana derajat inflamasinya masih tinggi.

Pemberian ketamine menyebabkan faktor transkripsi NF-kB mempunyai peranan krusial pada proses inflamasi. Aktivasi NF-kB dapat menuju kearah transkripsi dari protein-protein proinflamasi.Ketamin menghambat aktivasi NF-kB melalui penekanan degradasi IkB-á dan translokasi NF-kB sehingga akan menghambat produksi sitokain proinflamasi. Ketamin mensupresi produksi LPS-induced TNF- ,IL-6 dan IL-8 dan rhTNF-induced IL-6andIL-8 dalam darah manusia. TNF- adalah sitokin pertama yang timbul setelah stimulasi LPS, yang kemudian menstimulasi sekresi IL-6 and IL-8 dari makrofag monosit, neutrofil, dan sel endotel. Supresi ketamin pada produksi LPS induced IL-6 and IL-8 disebabkan efek inhibisi ketamin pada produksi LPS-induced TNF-.

\section{DAFTAR PUSTAKA}

Alscher K.T., Phang P.T., McDonald T.E. dan Walley K.R., 2001. Enteral feeding decreases gut apoptosis, permeability, and lung inflammation during murine endotoxemia, American Journal of Physiology-Gastrointestinal and Liver Physiology, 281(2): pp. G569-G576.

Birnbaum, J., Klotz, E., Spies, C.D., Lorenz, B., Stuebs, P., Hein, O.V., Gründling, M., Pavlovic, D., Usichenko, T., Wendt, M. and Kox, W.J., 2006. Effects of dopexamine on the intestinal microvascular blood flow and leucocyte activation in a sepsis model in rats. Critical Care, 10(4), p.R117.

Guntur AH.The Role Cytokine of the Pathogenesis of SIRS - Sepsis. Perspektif Masa Depan Imunologi Infeksi. International Journal on Immunorehabilitation $2003 ; 4$ : 23-0.

Gurfinkel R., Czeiger D., Douvdevani A., Shapira Y., Artru A.A., Sufaro Y., et al., 2006.
Ketamine improves survival in burn injury followed by sepsis in rats, Anesthesia \& Analgesia, 103(2): pp. 396-402.

Hirota K. dan Lambert D. 2011, 'Ketamine: new uses for an old drug?'.British Jrnl Anaesthesia.

Kirsten, P et al. 2003. Molecular basis of endothelial dysfunction in sepsis. Cardiovascular Research 60 (2003) 49-57.

Loix S., De Kock M. dan Henin P., 2011. The antiinflammatory effects of ketamine: state of the art, Acta Anaesthesiol Belg, 62(1): pp. 4758.

O'Brien J.M., Ali N.A. dan Abraham E., 2005. Year in review in Critical Care, 2004: sepsis and multi-organ failure, Critical Care, 9(4): p. 409

Tripathi P. dan Aggarwal A., 2006. NF-kB transcription factor: a key player in the generation of immune response, CURRENT SCIENCE-BANGALORE-, 90(4): p. 519. 